\title{
Корекція функціонального статүсу ендотелію як потенційної мішені у хворих із серцево- судинними захворюваннями та метаболічними розладами
}

\section{О.В. Курята, М.М. Гречаник}

ДУ «Дніпропетровська медична академія міністерства охорони здоров'я України»

\begin{abstract}
Резюме. Серцево-судинні (СС3) та обмінні захворювання (такі як ожиріння та цукровий діабет) наразі $\epsilon$ основними проблемами зі здоров'ям у всьому світі. Одним із найважливіших патофізіологічних зв'язків між цими станами $є$ наявність оксиду азоту (NO), який постійно виробляється з умовно незамінної амінокислоти L-аргініну. NO є важливою паракринною речовиною, яка продукується ендотелієм для регуляції судинного тонусу. Розвиток і прогресування атеросклерозу пов'язано з дисфункцією ендотелію та зниженням біодоступності NO. Встановлено, що ожиріння також пов'язано зі зменшенням продукції NO, викликаної порушенням біодоступності його субстрату — аргініну, а збільшенню вмісту аргініну в ендотелії запобігає гіпертензія, яка часто поєднується з ожирінням. L-аргінін є амінокислотою, необхідною ферменту ендотеліальній NO-синтазі (eNOS) для продукції NO. Мета - бібліографічний огляд наукових публікацій. Результати. У даному огляді розглянуто фізіологічну роль NO у функціонуванні різних систем організму. Наведено дані щодо метаболізму L-аргініну, його біодоступності та механізмів дії. Проаналізовано літературні дані про ефективність і безпечність застосування різних доз L-аргініну в пацієнтів з ожирінням, цукровим діабетом, інсулінорезистентністю (IP) та артеріальною гіпертензією. Висновки. Питання дози та тривалості застосування аргініну сьогодні вимагають подальшого вивчення. Результати багатьох досліджень, в яких оцінювали використання аргініну в дорослих з ожирінням, дозволяють припустити, що аргінін може бути безпечним, недорогим і ефективним терапевтичним засобом за ожиріння та позитивно впливає на корекцію метаболічних процесів, а саме на IP. Ефективність застосування L-аргініну
\end{abstract}

* Адреса для листування (Correspondence): ДУ «Дніпропетровська медична академія МО3 України», вул. В. Вернадського, буд. 9, м. Дніпро, 49044, Україна.

E-mail: plomami@i.ua

() О.В. Курята, М.М. Гречаник 
Оригінальні дослідження

як додаткової терапії до основної схеми лікування отримала підтвердження за артеріальної гіпертензії, цукрового діабету та IP. Аналіз літератури свідчить, що застосування L-аргініну є безпечним у діапазоні до 30 г на добу, хоча в більшості досліджень використовували дози від 6 до 12 г на добу.

Ключові слова: L-аргінін, ендотеліальна дисфункція, артеріальна гіпертензія, ожиріння, діабет, інсулінорезистентність.

Сериево-судинні (ССЗ) та обмінні захворювання (такі як ожиріння та иукровий діабет) наразі є основними проблемами зі здоров'ям у всьому світі. За результатами досліджень, у хворих на иукровий діабет розвиток ішемічної хвороби серия, інфаркту міокарда та інших ССЗ підвищено в 2-4 рази [1], що має велике економічне значення для пачієнта та начіональної системи охорони здоров'я. 3 иієї причини пошук додаткових та альтернативних методів терапї становить найбільший інтерес [1].

Серед немедикаментозних методів терапії широко вивчалися фізичні вправи та корекція харчування через їх потенційні вигоди [25]. Доведено позитивний вплив додаткового використання до основної схеми терапії амінокислот [6], вітамінів [7], жирних кислот [8], білків у хворих із ССЗ і метаболічними ускладненнями як інструменту для поліпшення імунної, нервової, серцево-судинної, метаболічної та ендокринної функцій. Цікаво, що одним із найважливіших патофізіологічних зв'язків між цими патологічними станами є наявність оксиду азоту (NO), який постійно виробляється з умовно незамінної амінокислоти L-аргініну [9].

Відомо, що L-аргінін було вперше виділено 1886 року E. Schulze i E. Steiger, а структуру його встановлено E. Schulze i E. Winterstei в 1897 році [10]. L-аргінін використовується декількома шляхами для синтезу білка та низькомолекулярних біоактивних речовин (наприклад, оксиду азоту, орнітину, проліну, креатину та поліамінів). Крім того, аргінін регулює клітинні сигнальні шляхи й експресію генів для поліпшення серцево-судинної функції, збільшення чутливості до інсуліну [11], збільшення м'язової маси та зменшення ожиріння в людей. Фізіологічна потреба тканин і органів в аргініні задовольняється його ендогенним синтезом або надходженням з їжею, проте в умовах стресу або хвороби ця амінокислота стає ессенціальною [12]. Після надходження 3 їжею L-аргінін всмоктується в тонкому кишечнику та транспортується в печінку, де основна його кількість утилізується в орнітиновому циклі [13]. Частина L-аргініну, що не метаболізувалася в печінці, використовується як субстрат для синтезу оксиду азоту (NO) [10], який є найважливішою субстанцією, що продукується судинним ендотелієм і впливає на регуляцію судинного тонусу.

Синтез NO 3 L-аргініну відбувається за допомогою ферменту NO-синтази (NOS), другим продуктом реакції є L-цитрулін [14]. Існує декілька ізоформ NOS, названих за типом клітин, з яких їх вперше було виділено нейрональна (nNOS, NOS I), макрофагальна (iNOS, NOS II) та ендотеліальна (eNOS, NOS III) [10]. Саме eNOS локалізується в ендотеліальних клітинах і відповідає за синтез базального рівня і його зміну у відповідь на фізичні навантаження та хімічні стимули брадикініну [15], який відіграє важливу роль у реалізації механізмів локальної ендотеліальної цитопротекції, підтриманні судинного гомеостазу та фізіологічній регуляції артеріального тиску (AT). Крім того, eNOS виявлено і в інших клітинах і тканинах, наприклад у кардіоміоцитах, еритроцитах, мегакаріоцитах і тромбоцитах [10].

iNOS у судинної мережі присутня не лише в макрофагах, а й у лімфоцитах, ендотеліальних клітинах, клітинах гладеньких м'язів або фібробластах. Вона активується під впливом бактеріальних ендотоксинів і запальних цитокінів, таких як чинник некрозу пухлин $\alpha$ та інтерлейкіни, не залежить від кальцію та викликає синтез NO у високих концентраціях (у 1000 разів вищих порівняно з $\mathrm{eNOS}$ ). У свою чергу, nNOS синтезує NO у фізіологічних кількостях, переважно як трансмітера 
в головному мозку та периферичній нервовій системі.

NO відіграє важливу роль у фізіологічних процесах організму, справляючи широкий спектр біорегуляторних ефектів (таблиця 1) [11]. Він каталізує утворення циклічного гуанозинмонофосфату (цГМФ), який і зумовлює більшість фізіологічних ефектів NO. Проте сьогодні відомі й інші ефекти NO, незалежні від активації гуанілатциклази або навіть NOS, включаючи посттрансляційну модифікацію білків, ліпідів та інших біомолекул. Іншими можливими мішенями для $\mathrm{NO} є$ розчинний аденозиндифосфат (АДФ) - рибозілюючий фермент і чинники транскрипції, через які NO може безпосередньо впливати на транскрипцію генів і трансляцію іРНК.

Роль NO в підтримці судинного гомеостазу зводиться до регуляції судинного тонусу, проліферації й апоптозу, а також регуляції оксидантних процесів. Крім того, NO притаманні ангіопротективні властивості [18]. NO також відповідальний за протизапальні ефекти, такі як пригнічення експресії молекул клітинної адгезії ICAM-1 (intercellular adhesion molecules 1), VCAM-1 (vascular cellular adhesion molecules 1) і тканинного чинника;

Таблиця 1. Роль оксиду азоту у функціонуванні різних систем організму [16]

\begin{tabular}{|c|c|}
\hline $\begin{array}{l}\text { Функціональна } \\
\text { система організму }\end{array}$ & Фізіологічна реакція \\
\hline Серцево-судинна & $\begin{array}{l}\text { Релаксація кровоносних судин } \\
\text { мозку, сітківки, серця, легень, нирок, } \\
\text { кишечника, серцевого м'яза }\end{array}$ \\
\hline $\begin{array}{l}\text { Дихальна, травна } \\
\text { та урогенітальна }\end{array}$ & $\begin{array}{l}\text { Релаксація гладеньком'язових тканин } \\
\text { трахеї, шлунку, кишечника, сечового } \\
\text { міхура, матки }\end{array}$ \\
\hline $\begin{array}{l}\text { Центральна } \\
\text { та периферична } \\
\text { нервова }\end{array}$ & $\begin{array}{l}\text { Нейромодулююча активність, яка } \\
\text { визначає довгострокове потенціювання, } \\
\text { формування пам'яті, сприйняття болю, } \\
\text { зоровий аналіз }\end{array}$ \\
\hline Ендокринна & $\begin{array}{l}\text { Регуляція синтезу та секреції гормонів: } \\
\text { інсуліну, пролактину, тироксину, } \\
\text { паратиреоїдного гормону, гормонів } \\
\text { надниркових залоз, гормонів } \\
\text { репродуктивного циклу }\end{array}$ \\
\hline Система гемостазу & $\begin{array}{l}\text { Регуляція взаємодії лейкоцитів зі } \\
\text { стінками судин. Регуляція активності } \\
\text { тромбоцитів [17] }\end{array}$ \\
\hline Імунна & $\begin{array}{l}\text { Антипатогенні реакції, неспецифічна } \\
\text { цитотоксичність, протипухлинний } \\
\text { захист, патогенез токсемії, відторгнення } \\
\text { трансплантата }\end{array}$ \\
\hline
\end{tabular}

пригнічення виділення хемокінів, таких як MCP-1 (monocyte chemoattractant protein 1). До того ж, NO блокує агрегацію тромбоцитів і справляє фібринолітичний ефект [19].

За нормального функціонування ендотелію NO справляє антиатерогенний ефект: пригнічує утворення комплексів окисленого холестерину з ліпопротеїнами низької щільності (ЛПНЩ), запобігає вазоконстрикторним ефектам тромбоксану $\mathrm{A}_{2}$, серотоніну, що виділяються 3 тромбоцитів, знижує стабільність мРНК, моноцитарного хемотаксичного чинника, перешкоджає адгезії та агрегації тромбоцитів (цГМФ-залежний механізм), пригнічуе експресію прозапальних генів (NF-kB). Недостатній синтез NO призводить до ушкодження мембран клітин продуктами вільнорадикального окислення, до клітинної дисфункції, зниження кровобігу, порушення транспорту глюкози та секреції інсуліну, IP, гіпертонії та діабету.

Серед механізмів, що складають підгрунтя зниження продукції або доступності NO за метаболічних порушень і СС3, можна віднести зниження рівня інсуліну в крові, збільшення вироблення ангіотензину II (АнгіоII), гіпергомоцистеїнемію, підвищення синтезу асиметричного диметиларгініну (ADMA) та низьку концентрацію L-аргініну в плазмі [20]. В умовах зниженого синтезу NO захисні механізми не функціонують, отже, запускаються механізми атерогенезу. Цікаво, що L-аргінін не знижує рівень холестерину в крові, але в його присутності холестерин втрачає здатність відкладатися на стінках судин [21]. Клінічні дослідження 3 використанням перорального лікування L-аргініном хворих із гіперхолестеринемією показали, що він поліпшує ендотелій-залежну вазодилятацію [22], і це поліпшення є порівнянним або навіть більшим, ніж після використання гіполіпідемічної терапії, також було зафіксовано поліпшення ендотеліальної функції за гіперхолестеринемії після лікування L-аргініном у дозі 6,6 г на добу [5]. Плейотропні ефекти L-аргініну наведено в $\mathrm{CB}_{\text {в- }}$ ропейських рекомендаціях із парентеральної нутріціології (ESPEN Guidelines on Parenteral Nutrition: On Cardiology and Pneumology, 2009), і L-аргінін рекомендований до застосування у хворих із хронічною серцевою недостатністю [23]. 
Оригінальні дослідження

Отже, додавання L-аргініну вважається потенційною терапією для лікування сериевосудинних та метаболічних захворювань, спрямованою на нормалізащію рівня NO, що сприяє поліпшенню біодоступності еNOS $i$ поліпшує функціональний стан ендотелію за ішемічної хвороби серця, гіпертонічної хвороби, серцевої недостатності, але питання добору дози для різних патологічних станів досі вивчається. За низької концентрації в плазмі крові L-аргінін сприяє поліпшенню ендотеліальної функції; у середній концентрації може справляти пряму вазодилятацію внаслідок стимуляції секреції інсуліну та гормону росту; високі рівні L-аргініну викликають неспецифічну вазодилятацію. Фармакокінетичні дослідження виявили, що пік концентрації аргініну в плазмі становив 50,0 23,4 мг/мл через 60 хв після приймання 10 г аргініну натще у хворих із базовою концентрацією аргініну 15,1 22,6 мг/мл. Автори встановили, що 20\% аргініну поглинається після приймання пероральної дози 10 г, а з часом концентрація аргініну в плазмі знижувалася, але не поверталася до базового рівня навіть через 8 год. [24]. В іншому дослідженні [25] повідомили, що після перорального приймання аргініну в дозі 6 г його пікова концентрація спостерігалася через 90 хв., і біодоступність становила $70 \%$.

Питання безпеки використання аргініну детально вивчено в праці [26], яка включала аналіз 38 клінічних випробувань із використанням аргініну в дорослих із 1990 по 2008 рр., у тому числі в популяціях людей похилого віку та осіб із патологією ниркової, дихальної та серцево-судинної систем. Пацієнтів із певними шлунково-кишковими захворюваннями, злоякісними новоутвореннями, сильними опіками та травми було виключено. Оцінювали небажані ефекти на печінку та функції нирок. Автори не виявили жодних побічних ефектів використання аргініну, тобто література демонструє високий рівень безпечності аргініну [27]. Найбільше наразі дослідження, яке включало 792 пацієнти з гострим інфарктом міокарда, які приймали аргінін у дозі 9 г на добу порівняно з плацебо протягом 30 діб не виявило побічних явищ або реакцій [28].

Питання дози і тривалості застосування аргініну на сьогоднішній день потребують подальшого вивчення. За результатами до- сліджень призначення добової дози аргініну коливається від 3 до 42 г/д [26], а допустима максимальна доза перорального аргініну для його максимального всмоктування також широко відрізняється, ймовірно, внаслідок використання різних лікарських форм (капсула, розчин), що також впливає на переносимість, і потребує більш довгострокових досліджень [27]. У дослідженні авторів із залученням здорових добровольців показана добра переносимість внутрішньовенного та перорального аргініну в дозі менше 30 г/добу [29].

Роль аргініну в патологічних процесах

Ожиріння, інсулінорезистентність, иукровий діабет 2-го типу (ЦД2)

Встановлено, що ожиріння пов'язано зі зменшенням продукиї NO, викликаної порушенням біодоступності його субстрату - аргініну, а збільшення вмісту аргініну в ендотелії запобігає гіпертензї [13], яка часто поєднується з ожирінням [30]. Результати багатьох досліджень, в яких оцінювали використання аргініну в дорослих з ожирінням, дозволяють припустити, що аргінін може бути безпечним, недорогим і ефективним терапевтичним засобом за ожиріння та позитивно впливає на корекиію метаболічних прочесів [31], а саме на IP.

Josianne Rodrigues-Krause та співавтори 2019 року в журналі Nutrients представили систематичний огляд і мета-аналіз, метою якого було узагальнення результатів рандомізованих контрольованих досліджень (РКІ), які оцінювали ефекти добавки L-аргініну порівняно з плацебо в людей із СС 3, ожирінням та/ або діабетом та обгрунтування використання добавки L-аргініну. Проаналізовано 3743 потенційно ревалентні цитати, 13 досліджень з участю 723 пацієнтів було включено до мета-огдяду (358 учасників, які отримували аргінін, і 365 учасників, які отримували плацебо). 3 них два дослідження включали хворих на ожиріння та/або ЦД2. ССЗ було виявлено в 443 учасників: 219 хворих на ішемічну хворобу серця, 136 - із хворобою периферичних артерій, 30 - із серцевою недостатністю, 38 - із стенокардією, 20 - 3 артеросклерозом. Віковий діапазон учасників становив від 33 до 73 років, чоловіків і жінок, хоча чоловіча стать переважала в 10 дослідженнях. У таблиці 2 наведено описові характеристики деяких включених досліджень [27]. Зафіксовано по- 
таблиця 2. Клінічні дослідження, що включають пероральне введення аргініну дорослим з ожирінням, інсулінорезистентністю та цукровим діабетом 2-го типу

\begin{tabular}{|c|c|c|c|c|c|}
\hline Суб'єкт дослідження & n & $\begin{array}{l}\text { Загальна добова доза, частота та } \\
\text { тривалість приймання аргініну }\end{array}$ & $\begin{array}{l}\text { Несприятливі } \\
\text { події }\end{array}$ & $\begin{array}{l}\text { Сприятливий вплив } \\
\text { аргініну }\end{array}$ & $\begin{array}{l}\text { Поси- } \\
\text { лання }\end{array}$ \\
\hline $\begin{array}{l}\text { Хворі з метаболічним } \\
\text { синдромом і поруше- } \\
\text { ною толерантністю } \\
\text { до глюкози }\end{array}$ & 144 & $\begin{array}{l}\text { 6,4 г/д.; } 2 \text { дози на день протягом } \\
18 \text { місяців (додатковий період спо- } \\
\text { стереження } 12 \text { місяців без додавання } \\
\text { аргініну) }\end{array}$ & $\begin{array}{l}\text { Зазвичай незначні } \\
\text { й однаково по- } \\
\text { ширені серед груп } \\
\text { аргінін і плацебо }\end{array}$ & $\begin{array}{l}\text { Втрата жиру; більший \% } \\
\text { повернення до нормогліке- } \\
\text { мії, ніж у групі плацебо }\end{array}$ & [33] \\
\hline $\begin{array}{l}\text { Хворі із ЦД2 і вісцераль- } \\
\text { ним ожирінням }\end{array}$ & 33 & $\begin{array}{l}\text { 8,3 г/д. } \\
\text { на } 21 \text { день }\end{array}$ & немає & $\begin{array}{l}\text { Поліпшення метаболічних } \\
\text { профілів; втрата жиру }\end{array}$ & {$[34]$} \\
\hline $\begin{array}{l}\text { Хворі з порушеною то- } \\
\text { лерантністю до глюкози }\end{array}$ & 30 & $\begin{array}{l}6 \text { г/д.; } \\
2 \text { дози/добу протягом } 6 \text { міс. }\end{array}$ & Немає & $\begin{array}{l}\text { Поліпшення ендотеліальної } \\
\text { функції; підвищення чутли- } \\
\text { вості до інсуліну; зниження } \\
\text { запальних маркерів }\end{array}$ & {$[35]$} \\
\hline $\begin{array}{l}\text { Хворі із ЦД2 зі супут- } \\
\text { німи захворюваннями } \\
\text { периферичних артерій }\end{array}$ & 50 & 6 г/д.; 3 дози/добу протягом 2 міс. & Немає & $\begin{array}{l}\text { Поліпшення антиоксидант- } \\
\text { ного статусу; підвищення } \\
\text { концентрації NO }\end{array}$ & {$[36]$} \\
\hline Хворі з ожирінням & 20 & 9 г/д.; 3 дози/добу протягом 12 тижнів & $\begin{array}{l}\text { Жодної клінічно } \\
\text { значущої }\end{array}$ & $\begin{array}{l}\text { Зменшення обводу талії } \\
\text { та потенційно кількості } \\
\text { вісцерального жиру; } \\
\text { зниження маси та ІМT }\end{array}$ & {$[37]$} \\
\hline Хворі із ЦД2 & 12 & 9 г/д.; 3 дози в день протягом 30 днів & Немає & $\begin{array}{l}\text { Поліпшення печінкової } \\
\text { та периферичної чутливості } \\
\text { до інсуліну }\end{array}$ & {$[38]$} \\
\hline Пацієнти з ожирінням & 88 & $\begin{array}{l}\text { L-аргінін (9 г/добу) у формі капсул } \\
\text { протягом } 6 \text { місяців }\end{array}$ & Немає & Значне збільшення NO & {$[39]$} \\
\hline $\begin{array}{l}\text { Хворі чоловіки із ЦД2 } \\
\text { і гіпертонією }\end{array}$ & 24 & $\begin{array}{l}600 \text { мг N-ацетилцистеїну, } 1 \text { таблетка } \\
\text { двічі на день + L-аргінін (1200мг/добу), } \\
\text { один флакон протягом } 6 \text { місяців }\end{array}$ & Немає & $\begin{array}{l}\text { Зменшення товщини } \\
\text { комплексу інтима-медіа та } \\
\text { збільшення вмісту нітритів } \\
\text { і нітратів у плазмі }\end{array}$ & {$[40]$} \\
\hline
\end{tabular}

Примітка: не надано жодної інформачії про частоту приймання пероральних добавок аргініну суб'єктами дослідження.

ліпшення ендотелій-залежної вазодилятаціі, значне зниження артеріального тиску, позитивний вплив L-аргініну на продукцію $N O$ в пацієнтів з ожирінням та/або ЦД2 у поєднанні із CC3 [32].

У дослідженні [41] оцінювали вплив довгострокової терапії L-аргініном на ризик розвитку ЦД2 у 144 пацієнтів із порушеною толерантністю до глюкози (IP; середній IMT $\sim 30$ кг/м²; середній вік: 57,7 року), які отримували низьку дозу аргініну (6,4 г/день) або плацебо протягом 18 місяців. Після припинення лікування хворих спостерігалися ще протягом 12 місяців. Під час 18-місячної фази лікування відбулися значні зміни, включаючи збільшення концентрації аргініну в плазмі натще в групі, що одержувала аргінін (50,0 11,3 ммоль/л

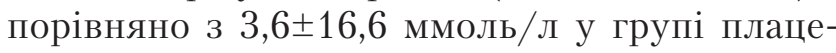
бо), значніше зниження маси жиру та більший відсоток хворих, які повернулися до нормоглікемії (42,4\% порівняно з 22,1\% відповідно), хоча абсолютна втрата маси тіла або показники метаболізму глюкози були однаковими в обох групах. Наприкінці розширеного періоду лише у $27,2 \%$ випадків серед хворих з IP, яких лікували аргініном, вона прогресувала до ЦД2 порівняно з 47,1\% у групі плацебо.

У рандомізованому контрольованому дослідженні 33 італійських пацієнти із Цд2 (середній IMT 39,1 кг/м²) отримували аргінін (8,3 г/добу) або плацебо протягом 21 дня. У групі з додаванням аргініну спостерігалося значне збільшення його концентрації в плазмі (3 81,8 $\pm 12,3$ мкмоль/л на початку дослідження

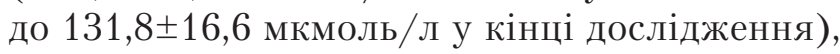
тоді як концентрація в групі плацебо не змінилися, що демонструє явну метаболічну перевагу аргініну [33, 34].

Описано ефективність 9 г аргініну на день (3 г 3 рази на добу) протягом 12 тижнів у 20 жінок віком від 18 до 40 років з ожирінням $(30 \leq \mathrm{IMT} \leq 40)-13$ жінок, які завершили дослідження, показали значне зменшення обводу талії на 5,5\% і зниження маси тіла на 2,9\% [37].

В іншому дослідженні в польського населення [36] вивчали використання L-аргініну 
Оригінальні дослідження

в 38 пацієнтів з атеросклеротичним захворюванням периферичних артерій нижніх кінцівок у поєднанні із ЦД2 порівняно з 12 здоровими. Усіх лікували низькою дозою аргініну (6 г/добу) протягом 2 міс. Не знайдено впливу на рівень глюкози натще або концентрацію глікованого гемоглобіну, але автори виявили значне збільшення концентрації NO та загального антиоксидантного статусу [42].

Отже, виявлено позитивний вплив L-аргініну за даних патологічних станів, що свідчить про можливість його використання як додаткової терапії та необхідність подальшого вивчення його ефектів.

\section{Артеріальна гіпертензія}

Відомо, що NO, який продукується в ендотелії судин, відповідає за релаксацію гладеньких м'язів [22] і необхідний для зниження артеріального тиску, а будь-яке поліпшення функції ендотелію сприяє профілактиці CC3 [43]. Лікування L-аргініном приводить до помірного зниження систолічного та діастолічного артеріального тиску [10]. Основні потенційні механізми дії L-аргініну за гіпертензії наведено в таблиці 3.

таблиця 3. Потенційні механізми дії L-аргініну за гіпертензії

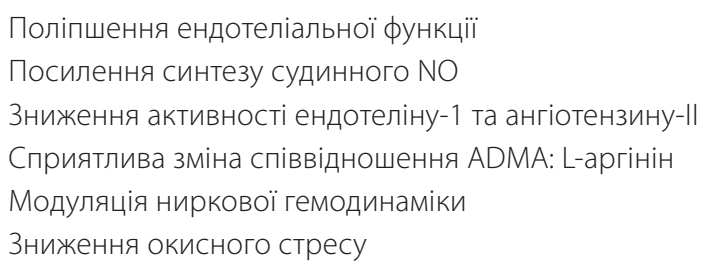

За даними літератури, у пацієнтів з артеріальною гіпертензією приймання L-аргініну ефективно знижує як систолічний (САТ), так і діастолічний (ДАТ) артеріальний тиск (від 2,2 мм рт. ст. до 5,4 мм рт. ст. і від 2,7 мм рт. ст. до 3,1 мм рт. ст. відповідно) [17]. Мета-аналіз 11 рандомізованих подвійних сліпих плацебо-контрольованих досліджень за участю 387 осіб із дозами аргініну в діапазоні від 4 г/добу до 24 г/добу протягом 2-24 тижнів показав, що добавки аргініну значно знижували САТ на $\sim 5$ мм рт. ст. і ДАТ на 3 мм рт. ст. $(\mathrm{p}<0,001$ для обох груп) [44]. У невеликому контрольованому дослідженні [45] у пацієнтів 3 артеріальною гіпертензією, рефрактерною до еналаприлу та гідрохлоротіазиду, виявлено сприятливу відповідь на введення до схе- ми лікування L-аргініну перорально в дозі 6 г на добу.

У проспективному подвійному сліпому рандомізованому клінічному дослідженні виявлено значне поліпшення ендотелій-залежної

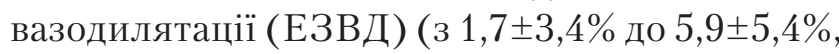
$\mathrm{p}=0,008)$ у 18 пацієнтів з ессенціальною гіпертензією на тлі приймання 6 г на добу L-аргініну. Перше дослідження гемодинамічних механізмів антигіпертензивного ефекту L-аргініну проведено із застосуванням L-аргініну в дозі 12 г на добу. У пацієнтів зменшився серцевий викид (на 0,4 л/хв.), ДАТ (на 1,9 мм рт. ст.), рівень гомоцистеїну в плазмі (на 2,0 мкмоль/л), збільшився період напруження шлуночків (на 3,4 мс). В іншому дослідженні обстежено 13 пацієнтів з артеріальною гіпертензією та мікроваскулярною стенокардією перед початком і після лікування L-аргініном (6 г на добу протягом 4 тижнів). Також під впливом L-аргініну значно поліпшилася якість життя, ФК стенокардії, знизився артеріальний тиск. ЕЗВД передпліччя, концентрація L-аргініну в плазмі значно збільшилися після лікування.

За результатами дослідження за участю 80 хворих віком 40-65 років з артеріальною гіпертензією 3 підвищенням артеріального тиску (АТ) від легкого до помірного ступеня, які не отримували антигіпертензивних препаратів та отримували дієтичний продукт $(2,4$ г L-аргініну, 3 мг вітаміну $\mathrm{B}_{6}, 0,4$ мг фолієвої кислоти, 2 мкг вітаміну $\mathrm{B}_{12}$ ) 2 рази на добу протягом 3 місяців, виявлено значуще поліпшення функції ендотелію ( $\mathrm{p}=0,0349)$, зниження рівня гомоцистеїну $(p=0,0001)$ і зниження CAT $(\mathrm{p}<0,0001)$. Також виявлено тенденцію до зниження ДАТ $(\mathrm{p}=0,093)$, що підтверджує ефективність, безпеку та стерпність L-аргініну для поліпшення серцево-судинного здоров’я [46].

Проспективне, рандомізоване подвійне сліпе дослідження показало прямий зв’язок між використанням L-аргініну в дозі 2 г або 4 г 3 рази на добу та зниженням АТ у 54 хворих на гіпертонічну хворобу. Пацієнти з гіпертонічною хворобою, які отримували L-аргінін у дозі 12 г/добу, мали нижчі САТ і ДАТ $[47,48]$.

За результатами нашого дослідження за участю 20 хворих із ревматоїдним артритом у поєднанні 3 артеріальною гіпертензією I-II ступеня, яким у комплексну терапію включали L-аргінін у формі розчину для перо- 
рального застосування 3 режимом дозування 15 мл 2 рази на добу (сумарна доза 6 г на добу) протягом 4 тижнів, у всіх хворих досягнуто нормалізації ендотеліальної функції (за наявності їі порушення у 95\% хворих перед початком лікування), суттєвого зменшення САТ і ДАТ (на 28,7\% і 26,4\% відповідно), зниження рівня адипонектину та зменшення IP [49].

Отже, аналіз літератури показав найбільшу ефективність L-аргініну саме в діапазоні доз від 6 г до 12 г на добу. Наразі ми маємо на ринку України Тівортін ${ }^{\circledR}$ фірми «Юрія-фарм», який у своєму складі містить L-аргініну аспартат у дозах не лише 4,2 г, а й 8,4 г. Слід зауважити, що використання препарату Тівортін ${ }^{\circledR}$ внутрішньовенно в дозі 4,2 г протягом 10 діб може бути продовжено використанням Тівортіну Аспартату у вигляді сиропу. Також «Юрія-фарм» пропонує посилену дозу L-аргініну, а саме Тівортін ${ }^{\circledR} 8,4$ г для в/в інфузій для пацієнтів високого серцево-судинного ризику, хворих з артеріальною гіпертензією, ожирінням, ІР і ЦД2. За результатами досліджень, використання L-аргініну саме в дозі 8,4 г у хворих даної категорії як додаткової терапї має найбільшу доказову базу та продемонструвало свій позитивний вплив на перебіг захворювання та механізми розвитку за відсутності значущих небажаних побічних ефектів.

Перспектива подальшого дослідження: на даному етапі в низці клінічних випробувань вивчається вплив L-аргініну на ліпідний профіль, проте результати залишаються неоднозначними. Мета-аналіз 12 рандомізованих контрольованих випробувань показав, що використання L-аргініну майже не впливає на показники загального холестерину, ліпопротеїнів низької та високої щільності, але зафіксовано значущий вплив на рівень тригліцеридів ( $<<0,001)$, що вимагає подальшого вивчення [50].

\section{Висновки}

1. Ефективність використання L-аргініну як додаткової терапії до основної схеми лікування знайшло підтвердження для артеріальній гіпертензії, ЦД2 та IP, що відображено в рекомендаціях із парентеральної нутріціології (ESPEN Guidelines on Parenteral Nutrition: On Cardiology and Pneumology, 2009).

2. Застосування L-аргініну продемонструвало свою безпечність у діапазоні доз до 30 г на добу, хоча в більшості досліджень використовувалась доза від 6 г до 12 г на добу.

Конфлікт інтересів. Автори заявляють про відсутність конфлікту інтересів $і$ власної фiнансової зацікавленості в ході підготовки даного огляду.

\section{Список використаної літератури}

1. De Rosa S, Arcidiacono B, Chiefari E, Brunetti A, Indolfi C, Foti DP. Type 2 Diabetes Mellitus and Cardiovascular Disease: Genetic and Epigenetic. Front Endocrinol. 2018;9:2.

2. Fayh AP, Krause M, Rodrigues-Krause J, Ribeiro JL, Ribeiro JP, Friedman R, Moreira JC, Reischak-Oliveira A. Effects of L-arginine supplementation on blood flow, oxidative stress status and exercise responses in young adults with uncomplicated type I diabetes. Eur J Nutr. 2013;52:975-983.

3. Krause M, Rodrigues-Krause J, O'Hagan C, Medlow P, Davison G, Susta D, Boreham C, Newsholme P, O'Donnell M, Murphy C et al. The effects of aerobic exercise training at two different intensities in obesity and type 2 diabetes: implications for oxidative stress low-grade inflammation and nitric oxide production. Eur J Appl Physiol. 2014;114:251-60.

4. Rodrigues-Krause J, Farinha JB, Krause M, Reischak-Oliveira A. Effects of dance interventions on cardiovascular risk with ageing: Systematic review and meta-analysis. Complement Med. 2016;29:16-28.

5. Tousoulis D, Antoniades C, Tentolouris C, Goumas G, Stefanadis C. L-Arginine in cardiovascular disease: dream or reality? Vasc Med. 2002;7:203-11.

6. Kashyap VS, Lakin RO, Campos P, Allemang M, Kim A, Sarac TP, Hausladen A, Stamler JS. The LargPAD Trial: Phase IIA evaluation of l-arginine infusion in patients with peripheral arterial disease. J Vasc Surg. 2017;66:187-94

7. Dimova R, Tankova T, Chakarova N. Siscovick DS, Barringer TA, Fretts $\mathrm{AM}, \mathrm{Wu} \mathrm{JH}$, Lichtenstein AH, Costello RB, KrisEtherton PM, Jacobson TA, Engler MB, Alger HM et al. Omega-3 Polyunsaturated Fatty Acid (Fish Oil) Supplementation and the Prevention of Clinic. J Nutr. 2017;147:1607-15.

8. Siscovick DS, Barringer TA, Fretts AM, Wu JH, Lichtenstein AH Costello RB. K-EPM, Jacobson T.A. EMBAHM et al. Omega-3 Polyunsaturated Fatty Acid (Fish Oil) Supplementation and the Prevention of Clinical Cardiovascular Disease: A Science Advisory From the American Heart Association. 2017, 135, e867-e884. Circulation. 2017;135:867-84

9. Newsholme P, Rebelato E, Abdulkader F, Krause M, Carpinelli A $\mathrm{CR}$. Reactive oxygen and nitrogen species generation, antioxidant defenses, and beta-cell function: a critical role for amino acids. 2012, 214, 11-20. J Endocrinol. 2012;214:11-20.

10. Бабушкина AB. L-аргинин с точки зрения доказательной медицины. Український кардіологічний журнал. 2009;6(74):1-9. (Babushkina AB. L-arginine in terms of evidence-based medicine. Ukrainian Cardiology Journal. 2009; 6 (74): 1-9.)

11. Алмакаева ЛГ, Литвинова ЕВ. Аргинин и его применение в медицине и фармации. Ліки України. 2011;1 (5):23-6. (Almakaeva LG, Litvinova E.V. Arginine and its use in medicine and pharmacy. Medicines of Ukraine. 2011; 1 (5): 23-6.)

12. Tousoulis D, Boger RH AC, Al E. Mechanisms of disease: L-arginine in coronary atherosclerosisa clinical perspective. Nat Clin Pr Cardiovasc Med. 2007;4:274-84.

13. Трещинская МА. Теоретические и практические аспекты применения L-аргинина с целью профилактики цереброваску лярной патологии. Український медичний часопис. [Internet] 2011. (Treschinskaya MA. Theoretical and practical aspects of the 
Оригінальні дослідження

use of L-arginine for the prevention of cerebrovascular pathology Ukrainian medical chronicle. [Internet] 2011.

14. Лутай МI, Бугаєнко ВВ, Моїсеєнко ОІ, Муштенко ЛО, Слободський BA. Значення L-аргініну в лікуванні хворих із серцево-судинною патологією. Український кардіологічний журнал. 2011;4:96-107. (Lutai MI, Bugaenko VV, Moiseenko OI, Mushtenko LO, Slobodskaya VA. The value of L-arginine in the treatment of patients with cardiovascular pathology. Ukrainian Cardiology Journal. 2011; 4: 96-107.)

15. Brunini TMC, Mendes-ribeiro AC, Ellory JC, Mann GE. Platelet nitric oxide synthesis in uremia and malnutrition: A role for L-arginine supplementation in vascular protection? Cardiovasc Res. 2007;73:359-67.

16. Степанов ЮМ, Кононов ИН, Филиппова АЮ. Аргинин в медицинской практике. Журн АМН України. 2004;10(1):340-52. (Stepanov YuM, Kononov IN, Filippova AYu. Arginine in medical practice. Journal of the Academy of Medical Sciences of Ukraine. 2004; 10 (1): 340-52.)

17. Соколова ЛК. Роль аргинина в физиологических процессах в норме и при патологических состояниях. Здоров'я України. 2018;(August):37-9. (Sokolova LK. The role of arginine in physiological processes is normal and in pathological conditions. Health of Ukraine. 2018; (August): 37-9.)

18. Ельский ВН, Ватутин НТ. К-, на Н.В. САМ. Роль дисфункции эндотелия в генезе сердечно-сосудистых заболеваний. Журн АМН України. 2008;1491):51-62. (Elsky VN, Vatutin NT. K-, on N.V. SAM. The role of endothelial dysfunction in the genesis of cardiovascular disease. Journal of the Academy of Medical Sciences of Ukraine. 2008; 1491): 51-62.)

19. Chatterjee A. CJD. Endothelial nitric oxide (NO) and its pathophysiologic regulation. Vasc Pharmacol. 2008;49(4-6):134-40.

20. Newsholme P, Homem De Bittencourt PI, De Vito G, Murphy C. KMS. Exercise and possible molecular mechanisms of protection from vascular disease and diabetes: the central role of ROS and nitric oxide. Clin Sci. 2009;118:341-9.

21. Коновчук ВМ, Максимчук НО, Максимчук ОА. Використання аргініну: клінічні та експериментальні результати Клінічна та експериментальна патологія. 2016;4 (58):143-6. (Konovchuk VM, Maksimchuk BUT, Maksimchuk OA. The use of arginine: clinical and experimental results. Clinical and experimental pathology. 2016; 4 (58): 143-6.)

22. Gornik HL, Creager MA. Arginine and Endothelial and Vascular Health. J Nutr. 2004;134:2880-7.

23. Anker SD, Laviano A, Filippatos G, John M, Paccagnella A, Ponikowski P. SAM. ESPEN guidelines on parenteral nutrition: on cardiology and pneumology. Clin Nutr. 2009;28 (4):455-60.

24. Evans RW, Fernstrom JD, Thompson J, Morris SM Jr. KLH. Biochemical responses of healthy subjects during dietary supplementation with L-arginine. J Nutr Biochem. 2004;15:534-9.

25. Bode-Boger SM, Boger RH, Galland A, Tsikas D FJ. L-arginine-induced vasodilation in healthy humans: pharmacokineticpharmacodynamic relationship. $\mathrm{Br} \mathrm{J}$ Clin Pharmacol. 1998;46:489-97.

26. Shao A HJ. Risk assessment for the amino acids taurine, L-glutamine and L-arginine. Regul Toxicol Pharmacol. 2008;(50):376-99.

27. McNeal CJ, Meininger CJ, Reddy D, Wilborn CD, Wu G. Safety and Effectiveness of Arginine in Adults. J Nutr [Internet]. 2016;146(12):2587S-2593S. Available from: http://jn.nutrition. org/cgi/doi/10.3945/jn.116.234740

28. Bednarz B, Jaxa-Chamiec T, Gebalska J H' nska-CK, L. C 'nski. L-arginine supplementation prolongs exercise capacity in congestive heart failure. Kardiol Pol. 2004;60:348-53.

29. Bode-Boger SM. Effect of L-arginine supplementation on NO production in man. Eur J Clin Pharmacol. 2006;62:91-99.

30. Rajapakse NW, Head GA. KDM. Say NO to obesity- related hypertension: role of the L-arginine-nitric oxide pathway. Hypertension. 2016;(67, № 5.): P. 813-819.

31. Yang Y, Wu ZL, Jia SC, Dahanayaka S, Feng S, Meininger CJ M, CJ WG. Safety of long-term dietary supplementation with L-arginine in rats. Amino Acids. 2015;47:1909-20.

32. Rodrigues-krause J, Krause M, Marques I. Association of L-arginine supplementation with markers of endothelial function in patients with cardiovascular or metabolic disorders: A Systematic. Nutrients. 2019;11:1-18.
33. Lucotti P., Monti L. SE et al. Oral L-arginine supplementation improves endothelial function and ameliorates insulin sensitivity and inflammation in cardiopathic nondiabetic patients after an aortocoronary bypass. Metabolism. 2009;58(9):1270-1276.

34. Lucotti P, Setola E, Monti LD, Galluccio E, Costa S SE, Fermo I, Rabaiotti G, Gatti R PP. Beneficial effects of a longterm oral L-arginine treatment added to a hypocaloric diet and exercise training program in obese, insulin-resistant type 2 diabetic patients. Am J Physiol Endocrinol Metab. 2006;291:906-12.

35. Lucotti P, Monti L, Setola E, La Canna G, Castiglioni A, Rossodivita A, Pala MG, Formica F, Paolini G, Catapano AL et al. Oral L-arginine supplementation improves endothelial function and ameliorates insulin sensitivity and inflammation in cardiopathic nondiabetic patients after an aortocoronary bypass. Metabolism. 2009;58:1270-6.

36. Jablecka A, Bogdanski P, Balcer N, Cieslewicz A, Skoluda A MK. The effect of oral L-arginine supplementation on fasting glucose, $\mathrm{HbA1c}$, nitric oxide and total antioxidant status in diabetic patients with atherosclerotic peripheral arterial disease of lower extremities. Eur Rev Med Pharmacol Sci. 2012;16:342-50.

37. Hurt RT, Ebbert JO, Schroeder DR, Croghan IT, Bauer BA M, SA, Miles JM MC. L-arginine for the treatment of centrally obese subjects: a pilot study. J Diet Suppl. 2014;11:40-52.

38. Palloshi A, Fragasso G PP et al. Effect of oral L-arginine on blood pressure and symptoms and endothelial function in patients with systemic hypertension, positive exercise tests, and normal coronary arteries. Am J Cardiol. 2004;93(7):933-935.

39. Bogdanski P, Szulinska M, Suliburska J, Pupek-Musialik D, Jablecka A. WH. Supplementation with L-arginine favorably influences plasminogen activator inhibitor type 1 concentration in obese patients. A randomized, double blind trial. 2013, 36, 221-226. J Endocrinol Invest. 2013;36:221-6.

40. Martina V, Masha A, Gigliardi VR, Brocato L, Manzato E, Berchio A, Massarenti P SF, Della Casa L, Bergamini S et al. Longterm $\mathrm{N}$-acetylcysteine and L-arginine administration reduces endothelial activation and systolic blood pressure in hypertensive patients with type 2 diabetes. Diabetes Care. 2008;31:940-4.

41. Monti LD, Setola E, Lucotti PC, Marrocco-Trischitta MM CM, Galluccio E, Poggi A, Mammi` C, Catapano AL, Comi G et al. Effect of a long-term oral L-arginine supplementation on glucose metabolism: randomized, double-blind, placebo-controlled trial. Diabetes Obes Metab. 2012;14:893-900.

42. Jabłecka A, Checiński P KH et al. The influence of two different doses of L-arginine oral supplementation on nitric oxide (NO) concentration and total antioxidant status (TAS) in atherosclerotic patients. Med Sci Monit. 2004;10 (1):29-32.

43. Appleton J. Arginine: clinical potential of a semi-essential amino acid. Altern Med Rev. 2002;7(6):512-22

44. Таращенко A. L-аргинин в лечении артериальной гипертензии: новые возможности. Здоров'я України. 2013;29. (Tarashchenko A. L arginine in the treatment of hypertension: new possibilities. I am healthy in Ukraine. 2013; 29.)

45. Pezza V, Bernardini F, Pezza E et al. Study of supplemental oral L-arginine in hypertensives treated with enalapril + hydrochlorothiazide. Am J Hypertens. 1998;11:1267-70.

46. Menzel D, Haller H, Wilhelm M RH. L-Arginine and B vitamins improve endothelial function in subjects with mild to moderate blood pressure elevation. Eur J Nutr. 2018;57(2):557-68.

47. Ast J, Jablecka A, Bogdanski P, Smolarek I KH, EC. Evaluation of the antihypertensive effect of $\mathrm{L}$-arginine supplementation in patients with mild hypertension assessed with ambulatory blood pressure monitoring. Med Sci Monit. 2010;16(15):266-71.

48. Sudar-Milovanovic E, Obradovic M, Jovanovic A, Zaric B, Zafirovic S, Panic A, Radak D IE. Benefits of L-Arginine on Cardiovascular System. Mini-Reviews Med Chem. 2016;16:94-103.

49. Kuryata O, Sirenko O. Endothelial Function, Insulin Resistance, Serum Adiponectin Level in Rheumatoid Arthritis Females with Renal Dysfunction and Its Dynamics with L-Arginine Aspartate Supplementation. Prensa Medica Argentina. 2017;103:6.

50. Hadi A, Arab A, Moradi S, Pantovic A, Clark C GE. The effect of l-arginine supplementation on lipid profile: a systematic review and meta-analysis of randomised controlled trials. $\mathrm{Br} \mathrm{J}$ Nutr. 2019;14(122 (9)):1021-32

(Надійшла до редакції 07.05.2020 р.) 


\section{Коррекция функционального статуса эндотелия как потенциальной мишени у пациентов с сердечно-сосудистыми заболеваниями и метаболическими расстройствами}

\section{А.В. Курята, М.М. Гречаник \\ ГУ «Днепропетровская медицинская академия МОЗ Украины»}

Резюме. Сердечно-сосудистые (СС3) и обменные заболевания (ожирение и сахарный диабет) в настоящее время являются основными проблемамы со здоровьем во всем мире. Одной из важнейших патофизиологических связей между этими состояниями является наличие оксида азота (NO), который постоянно вырабатывается из условно незаменимой аминокислоты L-аргинина. NO является важным паракринным веществом, выделяемым эндотелием для регуляции сосудистого тонуса. Развитие и прогрессирование атеросклероза связано с дисфункцией эндотелия и снижением биодоступности NO. Установлено, что ожирение также связано с уменьшением продукции NO, вызванным нарушением биодоступности его субстрата — аргинина, а увеличение содержания аргинина в эндотелии предотвращает гипертензию, которая часто сочетается с ожирением. L-аргинин является аминокислотой, необходимой ферменту эндотелиальной NO-синтазе (eNOS) для продукции NO. Цель - библиографический обзор научных публикаций. Результаты. В данном обзоре рассмотрена физиологическая роль NO в функционировании различных систем организма. Приведены данные о метаболизме L-аргинина, его биодоступности и механизмах действия. Проанализированы литературные данные об эффективности и безопасности применения различных доз L-аргинина у пациентов с ожирением сахарным диабетом, инсулинорезистентностью (ИР) и артериальной гипертензией. Выводы. Вопросы дозы и длительности применения аргинина на сегодняшний день требуют дальнейшего изучения. Результаты многих исследований, в которых оценивали использование аргинина у взрослых с ожирением, позволяют предположить, что аргинин может быть безопасным, недорогим и эффективным терапевтическим средством при ожирении и положительно влияет на коррекцию метаболических процессов, а именно на ИР. Эффективность применения L-аргинина в качестве дополнительной терапии к основной схеме лечения нашло подтверждение при артериальной гипертензии, сахарном диабете и ИР. Анализ литературы продемонстрировал безопасность применения L-аргинина в диапазоне доз до 30 г в сутки, хотя в большинстве исследований использовались дозы от 6 до 12 г в сутки.
Ключевые слова: L-аргинин, эндотелиальная дисфункция, артериальная гипертензия, ожирение, диабет, инсулинорезистентность.

\section{Correction of endothelial functional status as a potential target in patients with cardiovascular disease and metabolic disorders}

\section{A.V. Kuryata, M.M. Grechanyk \\ $\mathrm{SI}$ «Dnipropetrovsk Medical Academy of the Ministry of Health of Ukraine»}

Abstract. Cardiovascular (CVD) and metabolic diseases (such as obesity and diabetes) are currently major health problems worldwide. One of the most important pathophysiological connections between these conditions is the presence of nitric oxide (NO), which is constantly produced from a conditionally essential amino acid, namely L-arginine. NO is an important paracrine substance secreted by the endothelium to regulate vascular tone. The development and progression of atherosclerosis is associated with endothelial dysfunction and a decrease in the bioavailability of NO. It has been established that obesity is also associated with a decrease in NO production caused by a violation of the bioavailability of its substrate, arginine, and an increase in the arginine content in the endothelium prevents hypertension, which is often combined with obesity. L-arginine is an amino acid required by the enzyme endothelial NO synthase (eNOS), to produce NO. Purpose - bibliographic review of scientific publications. Results. This review discusses the physiological role of $\mathrm{NO}$ in the functioning of various body systems. Data on the metabolism of L-arginine, its bioavailability and mechanisms of action are given. The literature data on the effectiveness and safety of the use of various doses of L-arginine in patients with obesity, diabetes mellitus, insulin resistance (IR) and arterial hypertension are analyzed. Conclusion. Issues of dose and duration of arginine use today require further study. The results of many studies that evaluated the use of arginine in obese adults suggest that arginine can be a safe, inexpensive, and effective therapeutic agent for obesity and has a positive effect on the correction of metabolic processes, namely IR. The appointment of L-arginine as an adjunctive therapy to the main treatment regimen was confirmed in arterial hypertension, diabetes mellitus and IP. An analysis of the literature indicates that the administration of L-arginine demonstrated its safety in the range of the upper limit of $30 \mathrm{~g}$ per day, on the other hand, in most sources, a dose of 6 to $12 \mathrm{~g}$ per day was used.

Keywords: L-arginine, endothelial dysfunction, arterial hypertension, obesity, diabetes, insulin resistance. 